\title{
PENGARUH EDUKASI TENTANG KEBIJAKAN KAWASAN TANPA ROKOK TERHADAP PENGETAHUAN DAN SIKAP REMAJA DI KALIMANTAN SELATAN
}

\section{The Influence Of Education Policy That Without Cigarettes Of Knowledge And A Teenager In South Borneo}

Yeni Riza, Hilda Irianty, Mahmudah

Universitas Islam Kalimantan MAB Banjarmasin

(Yeniriza86@gmail.com, 08115122117)

\begin{abstract}
ABSTRAK
Provinsi Kalimantan selatan juga telah mengeluarkan Perda Provinsi No 4 Tahun 2012 Tentang Penyelenggaraan Kesehatan Tentang Kawasan Tanpa Rokok (KTR), 11 dari 13 $\mathrm{Kab} /$ Kota yang ada di Provinsi Kalimantan selatan sudah mengeluarkan regulasi tentang kebijakan KTR, tidak terkecuali dengan kota Banjarmasin yang telah mengeluarkan Perda Kota Banjarmasin No 7 Tahun 2013 Tentang Kawasan Tanpa Rokok. Banjarmasin juga merupakan salah satu kota pendidikan yang ada di pulau Kalimantan, yang menjadi rujukan bagi remaja untuk menuntut ilmu. Tujuan dari penelitian ini adalah mengetahui Pengaruh Edukasi tentang Kebijakan Kawasan Tanpa Rokok terhadap Pengetahuan dan Sikap Remaja di Kalimantan Selatan. Metode penelitian adalah kuantitatif menggunakan metode experimen dengan rancangan one group pretest dan post test design. Populasi dalam penelitian ini adalah seluruh remaja yang menempuh pendidikan di PTS Kalsel.Sampel dalam penelitian mahasiswa semester VI yaitu 393 orang.Hasil dari penelitian ini menggunakan uji Wilcoxon variabel pengetahuan $\mathrm{p}=0,000$ dan Sikap $\mathrm{p}=0,000$ yang artinya ada perbedaan yang signifikan antara pengetahuan dan sikap remaja sebelum dan sesudah diberikan edukasi tentang Kawasan Tanpa Rokok pada remaja di universitas-universitas swasta Kalimantan Selatan. Disarankan untuk meningkatkan derajat kesehatan mahasiswa khususnya di universitas-universitas di Kalimantan Selatan dengan peningkatan program penyuluhan dan sosialisasi berupa pemberian informasi serta edukasi tentang Kawasan Tanpa Rokok.
\end{abstract}

\section{Kata kunci : Kawasan tanpa rokok, pengetahuan, sikap, remaja}

\section{ABSTRACT}

The province of south borneo has also issued provincial regulations number 4 years 2012 on administering health concerning the region without cigarette, 11 of 13 district/cities existing in the province of south kalimantan had already made regulations in effect as well about the kind of policies ktr, no exception with the capital city banjarmasin that has been issued a local regulation the city of Banjarmasin number 7 years 2013 about the region without cigarette. Banjarmasin also happens to be one of your cities to the education system on the island of borneo, who be used as a reference for teenagers may learn to guard themselves. The purpose of this research is to know the influence of education about regional policies without cigarette to knowledge and attitude a south borneo.Research methodology is quantitative uses the method experimen to a draft one group pretest and post test design. Percent of the population in this 
research is that an entire kind of teenagers who have been studying in to private universities. Included in study of a student vi the semester 393 people.The result of this research using the knowledge wilcoxon variable $p=0,000$ and attitude $p=0,000$ which means there is a significant difference between knowledge and a teenager before and after given education concerning the region without smoke on youth in private universities south borneo. Suggested to improve health students especially in universitas-universitas in south kalimantan with increased program counseling and socialization the granting of information and education concerning the region without cigarettes.

Keywords: Region without cigarette,knowledge,attitude,teenagers 


\section{PENDAHULUAN}

Hasil Riset Kesehatan Dasar (Riskesdas) tahun 2013 menyebutkan prevalensi perokok diIndonesia mencapai36,5\% yang terdiri dari $68,8 \%$ perokok laki-laki dan $6,9 \%$ perokok perempuan. Fakta ini menempatkan Indonesia diperingkat ketiga dalam hal epidemik konsumsi rokok tertinggi didunia. Meningkatnya prevalensi merokok maka meningkat pula beban penyakit dan ekonomi akibat dari konsumsi rokok serta menurunnya derajat kesehatan dan kualitas Sumber Daya Manusia (SDM) Indonesia pada masa yang akan datang. ${ }^{1}$

Menurut penelitian yang dilakukan Global Adults Tobacco Survey (GATS) pada tahun 2013 diIndonesia penduduk kelompok umur $\geq 15$ tahun proporsi perokok pada laki-laki sebanyak 67,0\%, sedangkan pada perempuan yaitu sebanyak $2,7 \%$. Peningkatan prevalensi perokok terjadi pada kelompok umur 15-24 tahun, dari $17,3 \%$ (2007) menjadi $18,6 \%$ atau naik hampir 10\% dalam kurun waktu 3 tahun. Peningkatan juga terjadi pada kelompok umur produktif, yaitu 25-34 tahun dari 29,0\% (2007) menjadi 31,1\% (2010). ${ }^{2}$ Hampir $80 \%$ perokok mulai merokok ketika usianya belum mencapai 19 tahun. Hasil riskesdas pada tahun 2007, 2010, dan 2013 menunjukkan bahwa usia merokok pertama kali paling tinggi adalah 15-19 tahun.Hal ini di karenakan ketidaktahuan risiko mengenai bahaya adiktif rokok. Menurut data Riskesdas 2013 didapatkan trend usia merokok meningkat pada usia remaja usia 10-19 tahun. ${ }^{3}$

Menurut Undang-Undang Kesehatan No. 36 Tahun 2009 Pasal 115 menyatakan bahwa instansi pendidikan merupakan tempat yang dinyatakan sebagai kawasan tanpa rokok. Hasil penelitian yang dilakukan oleh Febriani (2014) menyatakan bahwa Universitas Sumatera Utara masih belum menerapkan kawasan tanpa rokok dilingkungan kampus, hal ini terlihat dari masih banyaknya para perokok yang dengan bebas merokok didalam lingkungan kampus. ${ }^{1}$ Hal ini juga terlihat dari masih banyaknya kegiatan di lingkungan kampus yang didukung oleh produsen rokok, seperti kegiatan sponsorship antara pihak universitas dengan produsen rokok. Provinsi Kalimantan selatan telah mengeluarkan Perda Provinsi No 4 Tahun 2012 Tentang Penyelenggaraan Kesehatan Bab IX Pasal 29 Tentang Kawasan Tanpa Rokok (KTR), 11 dari 13 Kabupaten/Kota yang ada di Provinsi Kalimantan Selatan sudah mengeluarkan regulasi tentang kebijakan KTR, tidak terkecuali dengan kota Banjarmasin yang telah mengeluarkan Perda Kota Banjarmasin No 7 Tahun 2013 Tentang KTR.

Kota Banjarmasin adalah salah satu kota besar di Indonesia merupakan ibu kota dari Provinsi Kalimantan 
Selatan,dan kabupaten/kota dengan penduduk paling banyak di Provinsi Kalimantan Selatan. Termasuk sebagai salah satu kota pendidikan yang ada di pulau Kalimantan, menjadi tempat rujukan menuntut ilmu para pelajar serta mahasiswa. Berdasarkan data yang diakses dari laman forlap dikti, Universitas Islam Kalimantan MAB Banjarmasin merupakan salah satu perguruan tinggi swasta terbesar di Kalimantan Selatan.

Penerapan KTR di Universitas Islam Kalimantan memang masih jauh dari harapan,karena dari 9 Fakultas yang ada di Universitas Islam Kalimantan hanya Fakultas Kesehatan Masyarakat lah yang sudah menerapkan KTR. Untuk peraturan KTR sebenarnya sudah diatur dalam Peraturan Daerah Kota Banjarmasin Nomor 7 tahun 2013, tentang Kawasan Tanpa Rokok yang mengatur tentang penerapan KTR dilingkungan kampus, sehingga fakultas-fakultas yang belum menerapkan KTR akan menjadi ancaman bagi civitas akademi di lingkungan kampus. Penerapan KTR di Universitas Islam Kalimantan tidak akan berjalan lancar tanpa adanya kerja sama antar fakultas yang ada di Universitas Islam Kalimantan. Tujuan penelitian untuk mengkaji bagaimana pengaruh edukasi tentang kebijakan Kawasan Tanpa Rokok (KTR) terhadap pengetahuan dan sikap remaja di Kalimantan Selatan.

\section{BAHAN DAN METODE}

Jenis penelitian ini adalah kuantitatif menggunakan metode experimen dengan rancangan one group pretest dan post test design yaitu suatu kelompok diberikan perlakuan,tetapi sebelumnya diberikan pre-test dan setelah itu dilakukan post-test. Penelitian dilaksanakan pada bulan April - Agustus 2018.Tempat penelitian dilaksanakan di Universitas - universitas swasta di Kalimantan Selatan yaitu Universitas Achmad Yani, Universitas Islam Kalimantan MAB, Universitas Nahdlatul Ulama dan Universitas Muhammadiyah Banjarmasin. Populasi dalam penelitian ini adalah seluruh remaja yang menempuh pendidikan di Universitas Swasta Banjarmasin sebanyak 22.130. Jumlah Sampel dari penelitian ini sebanyak 393 orang. Instrumen penelitian yang digunakan untuk mengukur atau menilai variabel penelitian adalah berupa kuesioner.

Analisis data menggunakan analisis univariat analisis ini digunakan untuk mengetahui pengetahuan responden tentang kebijkaan KTR sebelum dan sesudah diberikan edukasi, dan mengetahui sikap responden tentang kebijkaan KTR sebelum dan sesudah diberikan edukasi. Analisis bivariat dilakukan untuk melihat perbedaan pengetahuan dan sikap remaja pria pada saat sebelum dan sesudah diberikan edukasi dengan metode penyuluhan dan pembagian leflet tentang kebijkan KTR. Data dianalisis 
dengan bantuan komputer menggunakan uji statistik yaitu Paired Sample t-test jika data berdistribusi normal dan uji Wilcoxon jika data tidak berdistribusi normal. ${ }^{4}$

\section{HASIL}

Hasil penelitian didapatkan distribusi frekuensi responden menurut usia di Universitas Achmad Yani berusia diantara 20-25 tahun sebanyak 54 orang $(93,10 \%)$. Distribusi frekuensi responden menurut usia di Universitas Islam Kalimantan berusia diantara 20-25 tahun sebanyak 250 orang (86,80\%).Distribusi frekuensi responden menurut usia di Universitas Nahdlatul Ulama Kalsel berusia <20 tahun sebanyak 2 orang (100\%). Distribusi frekuensi responden menurut usia di Universitas Muhammadiyah Banjarmasin berusia $<20$ tahun sebanyak 29 orang $(64,44 \%)$.

Distribusi frekuensi responden berdasarkan pengetahuan sebelum diberikan edukasi tentang KTR pada remaja di universitas-universitas swasta Kalimantan Selatan Tahun 2018 bahwa sebagian besar responden berpengetahuan kurang sebanyak 233 orang $(59,28 \%)$.Distribusi frekuensi responden berdasarkan sikap sebelum diberikan edukasi tentang KTR pada remaja di universitas-universitas swasta Kalimantan Selatan Tahun 2018 bahwa sebagian besar responden bersikap positif sebanyak 245 orang $(62,34 \%)$.
Distribusi frekuensi responden berdasarkan pengetahuan sesudah diberikan edukasi tentang KTR pada remaja di universitas-universitas swasta Kalimantan Selatan Tahun 2018 bahwa sebagian besar responden berpengetahuan baik sebanyak 324 orang $(82,44 \%)$. Distribusi frekuensi responden berdasarkan sikap sesudah diberikan edukasi tentang KTR pada remaja di universitas-universitas swasta Kalimantan Selatan Tahun 2018 bahwa semua responden bersikap positif sebanyak 74 orang (100\%).

Data hasil penelitian pengetahuan dan sikap dari 393 responden tentang KTR diuji kenormalannya dengan uji kolmogorov smirnov hasil uji kenormalan pengetahuan pre test dan post test, sikap pre test dan post test di peroleh nilai $p$-value $<0,05$, yang berarti data tersebut berdistribusi tidak normal, maka pengolahan data tersebut dilakukan menggunakan uji Wilcoxon. Hasil pengolahan data menggunakan uji Wilcoxon. Distribusi frekuensi berdasarkan perbedaan pengetahuan responden sebelum dan sesudah diberikan edukasi tentang KTR pada remaja di universitas-universitas swasta Kalimantan Selatan diperoleh pengetahuan remaja tentang KTR sebelum diberikan Edukasi (pre test) rata-rata 1,80 dan setelah diberikan Edukasi (post test) rata-rata 2,70.

Hasil analisis menggunakan uji Wilcoxon Signet Rank Test dengan signifikasi (nilai p) $=0,000$. Karena signifikasi $\mathrm{p}<0,05$ berarti ada perbedaan 
yang signifikan antara pengetahuan remaja sebelum dan sesudah diberikan edukasi tentang KTR pada remaja di universitasuniversitas swasta Kalimantan Selatan.

Distribusi frekuensi berdasarkan perbedaan sikap responden sebelum dan sesudah diberikan edukasi tentang KTR pada remaja di universitas-universitas swasta Kalimantan Selatan diperoleh sikap remaja tentang KTR sebelum diberikan edukasi (pre test) rata-rata 1,47 dan setelah diberikan edukasi (post test) rata-rata 2,00.

Hasil analisis menggunakan uji Wilcoxon Signet Rank Test dengan signifikasi (nilai p) $=0,000$. Karena signifikasi $\mathrm{p}<0,05$ berarti ada perbedaan yang signifikan antara sikap remaja sebelum dan sesudah diberikan edukasi tentang KTR pada remaja di universitas-universitas swasta Kalimantan Selatan.

\section{PEMBAHASAN}

Pada hasil pengetahuan sebelum diberikan edukasi bahwa sebagian besar responden berpengetahuan kurang sebanyak 233 orang $(59,28 \%)$. Hal ini terlihat dari jawaban responden yang sebagian besar tidak tahu apa definisi sebenarnya dari KTR atau Kawasan Tanpa Asap Rokok dimana sebagian besar responden hanya mengetahui KTR sebatas kawasan atau area tidak boleh merokok saja, padahal defenisi sebenarnya dari KTR adalah ruangan atau area yang dinyatakan dilarang untuk kegiatan merokok atau kegiatan memproduksi, menjual, mengiklankan, dan/atau mempromosikan produk tembakau. Jadi KTR bukan hanya sekedar larangan merokok saja. Selain tentang definisi KTR nya, sebagian besar responden juga tidak mengetahui bahwa di ada Perda yang mengatur KTR ini, selain itu juga banyak responden yang juga tidak memahami daerah atau kawasan apa saja yang merupakan bagian dari KTR. Hasil penelitian ini menunjukan bahwa sebagian besar responden masih memiliki pengetahuan yang kurang mengenai Kawasan Tanpa Rokok.

Pengetahuan melakukan suatu tindakan, dapat dipengaruhi oleh sikap. Sikap memiliki tiga komponen yaitu kognitif, afektif, dan psikomotorik. $^{5}$ Jadi dalam tindakan seseorang tidak hanya aspek kognitif yang perlu diperhatikan. Perlu diperhatikan pula aspek afektif dan psikomotorik. ${ }^{6}$ Shaluhiyah (2006) menyebutkan bahwa sikap merupakan faktor yang paling berpengaruh pada praktik atau tindakan merokok seseorang. ${ }^{7}$ Dan Azwar (2007) juga menyatakan sikap berhubungan dengan tindakan merokok. Akan tetapi, informasi tentang rokok dan bahayanya tetap penting untuk mengubah sikap seseorang. ${ }^{8}$

Hasil sikap sebelum diberikan edukasi dapat dilihat bahwa sebagian besar responden bersikap positif sebanyak 245 orang $(62,34 \%)$. terlihat dalam jawaban kuesioner responden bahwa sebagian besar 
responden setuju terhadap pernyataan sikap aktifitas merokok sangat mengganggu orang lain yang tidak merokok", sedangkan sebanyak 148 responden (37.66\%) memiliki sikap yang negatif hal ini terlihat dalam responden menjawab kuesioner bahwa responden setuju terhadap pernyataan sikap "orang yang melanggar area kawasan tanpa rokok tidak harus diberi sanksi.

Notoatmodjo menjelaskan bahwa sikap merupakan respon atau reaksi yang masih tertutup dari seorang terhadap stimulus atau objek. Reaksi atau respon tersebut berupa memahami, merespon,menghargai, dan bertanggung jawab. Selain itu sikap merupakan dasar untuk membuat respon atau berperilaku dalam cara yang dipilihnya. ${ }^{5}$ Dari hasil penelitian pengetahuan sesudah diberi edukasi dilihat bahwa sebagian besar responden berpengetahuan baik sebanyak 324 orang $(82,44 \%)$. Hal ini menunjukkan adanya peningkatan pengetahuan setelah mendapatkan edukasi berupa penyuluhan dan pemberian leaflet. Faktor yang mempengaruhi perubahan tingkat pengetahuan setelah diberikan penyuluhan adalah sebagian besar responden dalam rentang umur 18-24 tahun dan sedang menempuh pendidikan di perguruan tinggi sehingg semakin mudah dalam menerima informasi berupa penyuluhan.

Sejalan dengan penelitian Salman (2014) memperlihatkan peningkatan nilai mean sebelum dan sesudah pendidikan kesehatan meningkat dari 2,51 menjadi 10,95 atau sebesar $8,44 .{ }^{9}$ Pendidikan kesehatan adalah suatu belajar yang berarti di dalam pendidikan itu terjadi proses pertumbuhan, perkembangan atau perubahan kearah dewasa, lebih baik, lebih matang pada diri individu, kelompok atau masyarakat. Setelah diberikan edukasi tentang KTR, didapatkan hasil meningkatnya pengetahuan responden yang sebelumnya lebih banyak pada kategori kuraang tetapi setelah diberikan edukasi menunukkan peningkatan pengetahuan menjadi kategori pengatahuan baik. hal ini karena responden telah diberikan informasi mengenai KTR. Informasi yang diperoleh baik dari pendidikan formal maupun non formal dapat memberikan pengaruh jangka pendek (immediate impact) sehingga menghasilkan perubahan atau peningkatan pengetahuan.

Serta Tabel 8 dapat dilihat bahwa semua responden bersikap positif sebanyak 360 orang $(91,6 \%)$. Sikap dibentuk melalui proses belajar sosial, yaitu proses dimana individu memperoleh informasi tingkah laku, atau sikap baru dari orang lain. Responden disini adalah remaja-remaja yang berusia 18-24 tahun dan sedang menjalani proses perkuliahan yang tentu lebih berpengalaman dibandingkan remaja yang tidak menempuh bangku perkuliahan. Remaja mendapatkan pembelajaran 
pengondisian instrumental dan belajar melalui pengamatan, pengondisian instrumental yang dimaksud adalah proses pembelajaran terjadi ketika suatu perilaku mendatangkan hasil yang menyenangkan bagi seseorang, maka perilaku tersebut akan diulang kembali. Hal itu juga yang terjadi pada remaja di universitas-universitas swasta yang ada di Kalimantan Selatan dalam menyikapi Kawasan Tanpa Asap Rokok.

Belajar melalui pengamatan yang dimaksud adalah proses pembelajaran dengan cara mengamati perilaku orang lain, kemudian dijadikan sebagai contoh untuk berperilaku serupa. Dalam keseharian, banyak sikap yang terbentuk karena aktif mengamati berita-berita dan gambar melalui koran, televisi, majalah dan media lainnya. $^{10}$ Setelah diberikan edukasi mengenai KTR, sikap remaja mengalami peningkatan, hal ini dapat disebabkan oleh faktor-faktor yang memengaruhi pembentukan sikap yaitu pengalaman pribadi, kebudayaan, orang lain yang dianggap penting, dan media massa. Dalam penelitian ini tidak menganalisis lebih j a u h mengenai faktor tersebut. Sikap adalah respon tertutup seseorang terhadap suatu stimulus atau objek. Notoatmodjo membagi sikap dalam tingkatan, remaja yang diberikan edukasi sikapnya berada dalam tingkatan pertama yaitu menerima, remaja mau dan memperhatikan stimulus yang diberikan tetapi ia tidak merespon, menghargai dan bertanggungjawab sehingga edukasi yang diberikan tidak terlalu memberikan arti bagi perubahan sikap ibu. ${ }^{4}$ Berdasarkan hasil uji kenormalan pengetahuan pre test dan post test, sikap pre test dan post test di peroleh nilai $p$-value $<0,05$, yang berarti data tersebut berdistribusi tidak normal, maka pengolahan data tersebut dilakukan menggunakan uji Wilcoxon.

Berdasarkan pengetahuan remaja tentang KTR sebelum diberikan Edukasi (pre test) rata-rata 1,80 dan setelah diberikan Edukasi (post test) rata-rata 2,70. Hasil analisis menggunakan uji Wilcoxon Signet Rank Test dengan signifikasi (nilai p) = 0,000 . Karena signifikasi $\mathrm{p}<0,05$ berarti ada perbedaan yang signifikan antara pengetahuan remaja sebelum dan sesudah diberikan edukasi tentang KTR pada remaja di universitas-universitas swasta Kalimantan Selatan. Hasil penelitian ini sejalan dengan penelitian Salman $(2014)^{14}$ diperoleh hasil uji statistik yang dilakukan dengan mengunakan uji $\mathrm{T}$ kelompok eksperimen sebesar 0,000 atau $\mathrm{p}<0,05$, maka Ho di tolak. Dapat disimpulkan bahwa pendidikan kesehatan memiliki efek yang signifikan terhadap perubahan tingkat pengetahuan remaja tentang dampak bahaya rokok.

Pendidikan kesehatan pada hakikatnya merupakan suatu kegiatan atau usaha menyampaikan pesan kesehatan kepada remaja. Adanya pesan tersebut, 
kelompok atau individu dapat memperoleh pengetahuan tentang kesehatan yang lebih baik. Pengetahuan tersebut pada akhirnya diharapkan dapat berpengaruh terhadap perilaku. Adanya pendidikan kesehatan tersebut, diharapkan dapat membawa akibat terhadap perubahan perilaku dari sasaran. ${ }^{4}$ Pengetahuan remaja tentang KTR adalah hasil tahu remaja tentang definisi KTR, Undang-undang yang mengatur KTR, dan kawasan KTR. Hal ini penting karena diharapkan pengetahuan tentang KTR ini dapat diterapkan dalam kehidupan seharihari, selain itu juga dapat menyebarluaskan informasi yang mereka miliki tentang KTR ke lingkungan sekitarnya.

Menurut Irmayanti (2007) salah satu faktor yang mempengaruhi pengetahuan adalah karena kekurangan informasi. ${ }^{11}$ Pemberian informasi melalui pendidikan dan pelatihan akan meningkatkan pengetahuan, selanjutnya akan menimbulkan kesadaran dan akhirnya seseorang akan melakukan praktek sesuai dengan pengetahuan yang dimiliki, meskipun memerlukan waktu yang lama. Sebelum seseorang mengadopsi praktek, ia harus terlebih dahulu tahu apa arti dan manfaat praktek tersebut bagi dirinya dan orang lain, dalam hal ini adalah penerapan KTR di lingkungan kampus. Setelah seseorang mengetahui, selanjutnya akan menilai atau bersikap. Secara teori perubahan praktek atau mengadopsi praktek baru itu mengikuti proses perubahan : pengetahuan, sikap dan praktek. Pengalaman dan penelitian juga membuktikan bahwa praktek yang didasari oleh pengetahuan akan lebih langgeng daripada praktek yang tidak didasari oleh pengetahuan. ${ }^{12}$

Berdasarkan sikap remaja tentang KTR sebelum diberikan edukasi (pre test) rata-rata 1,47 dan setelah diberikan edukasi (post test) rata-rata 2,00. Hasil analisis menggunakan uji Wilcoxon Signet Rank Test dengan signifikasi (nilai $\mathrm{p})=0,000$. Karena signifikasi $\mathrm{p}<0,05$ berarti ada perbedaan yang signifikan antara sikap remaja sebelum dan sesudah diberikan edukasi tentang KTR pada remaja di universitas-universitas swasta Kalimantan Selatan. Hasil penelitian sejalan dengan penelitian Rusmilawaty (2015) bahwa ada pengaruh penyuluhan dengan metode ceramah tentang bahaya rokok terhadap sikap perokok aktif sebelum dan setelah diberikan penyuluhan dengan nilai $\mathrm{p}=0,00$, atau dapat juga dikatakan bahwa penyuluhan tentang bahaya rokok berpengaruh secara signifikan terhadap peningkatan sikap remaja tentang KTR menjadi lebih baik. Peneliti berasumsi bahwa perbedaan ini dapat disebabkan oleh faktor : a) Pemberian edukasi menggunakan media berupa leaflet dimana media tersebut memperjelas ide atau pesan yang disampaikan selain itu juga dapat membantu mengingat kembali apa yang diajarkan. b) Pada saat edukasi terdapat hal-hal yang yang disampaikan sama persis dengan pertanyaan 
yang terdapat di kuesioner sehingga responden dapat langsung mengerti dan menjawab pertanyaan-pertanyaan posttest dengan benar. c) Informasi yang diberikan dibutuhkan oleh responden, sehingga pada saat penyuluhan responden antusias menyimak informasi yang disampaikan secara langsung. ${ }^{13}$ Newcomb dalam Soekidjo Notoatmodjo (2007) berpendapat bahwa sikap merupakan kesiapan atau kesediaan untuk bertindak dan bukan merupakan pelaksanaan motif tertentu. Sikap belum merupakan suatu tindakan atau aktifitas, tetapi merupakan predisposisi tindakan suatu perilaku. ${ }^{5}$ Azwar $(2008)^{14}$ mengatakan bahwa sikap mempengaruhi praktek lewat suatu proses pengambilan keputusan yang teliti dan beralasan dan dampaknya terbatas yang berarti bahwa seseorang akan melakukan suatu perbuatan apabila ia memandang perbuatan itu positif dan bila ia percaya bahwa orang lain ingin agar ia melakukannya. ${ }^{12}$

Beberapa penelitian telah dilakukan untuk mengetahui pengaruh pendidikan kesehatan terhadap perubahan prilaku remaja merokok. Diantaranya adalah penelitian oleh Nia (2007), ia menemukan fakta remaja sekolah yang terbiasa berada pada kawasan tampa rokok mempunyai kemungkinan 3,2 kali lebih tinggi untuk memiliki sikap positif dan 2,6 kali lebih tinggi untuk berhenti merokok dibandingkan remaja sekolah tidak merokok. ${ }^{15}$ Dilaporkan juga bahwa salah satu alasan remaja tidak merokok menolak untuk merokok adalah karna ia telah mengetahui bahaya rokok bagi kesehatan. ${ }^{16} \quad$ Penelitian tersebut membuktikan bahwa melalui pemberian informasi dan pendidikan kesehatan dapat merubah pengetahuan, sikap dan prilaku remaja terhadap rokok.

$$
\text { Tingkatan sikap menurut }
$$

Notoatmodjo (2007) terdiri dari berbagai tindakan yakni: menerima, merespon, menghargai, dan bertanggungjawab. ${ }^{5}$ Remaja yang memililki sikap yang baik lebih cenderung menerapkan perilaku KTR di lingkungan kampus karena lebih memperhatikan unsur-unsur dari KTR dibandingkan dengan remaja yang memiliki sikap yang kurang. Oleh sebab itu, sebagai tenaga kesehatan khususnya kesehatan masyarakat harus memberikan informasi yang cukup khususnya tentang KTR dalam upaya meningkatkan pengetahuan dan sikap serta dapat mencegah perilaku buruk dari pengguna rokok baik bahaya untuk perokok aktif maupun perokok pasifnya, sehingga dapat mencegah bahaya-bahaya yang ditimbulkan dari rokok seperti hipertensi, stroke dan diabetes mellitus.

\section{KESIMPULAN DAN SARAN}

Kesimpulan dari penelitian ini sebelum diberi edukasi sebagian besar responden berpengetahuan kurang sebanyak 233 orang $(59.28 \%)$ dan bersikap positif 
sebanyak 245 orang (62.34\%). Sesudah diberi edukasi sebagian besar responden berpengetahuan baik sebanyak 324 orang (82.44\%) dan semua responden bersikap positif sebanyak 360 orang (91.6\%) Ada perbedaan pengetahuan remaja sebelum dan sesudah diberikan Edukasi Tentang KTR Pada Remaja Di Universitas-Universitas Swasta Kalimantan Selatan. Sedangkan saran dari penelitian ini Bagi Peneliti mahasiswa dapat menggunakan hasil penelitian ini sebagai pertimbangan untuk dapat diteliti kembali pada tingkatan yang lebih spesifik. Hasil penelitian ini perlu pengembangan lebih lanjut pada instrumen serta subjek penelitian terkait perilaku merokok mahasiswa agar lebih berkembang dikemudian hari. Bagi institusi pendidikan memperhatikan perencanaan dan memantau pelaksanaan penelitian di bidang ilmu kesehatan secara komprehensif sehingga hasil penelitian dapat lebih mudah

\section{DAFTAR PUSTAKA}

1. Febriani, Tria. Pengaruh Persepsi Mahasiswa Terhadap Kawasan Tanpa Rokok (KTR) dan Dukungan penerapannya di Universitas Sumatera Utara. Karya Tulis Ilmiah stara satu Universitas Sumatera; 2014.

2. Kemenkes RI. Pedoman Pengembangan Kawasan Tanpa Rokok. Kemenkes RI. Jakarta; 2011.

3. Depkes RI. Hasil Riset Kesehatan Dasar (RISKESDAS) Departemen Kesehatan Republik Indonesia. Jakarta : Kementerian Kesehatan Republik dikembangkan dan dipertanggungjawabkan kebenarannya. Mengembangkan ilmu pengetahuan kesehatan masyarakat terkait perilaku merokok mahasiswa secara meluas dan dapat terus mewadahi mahasiswa dalam mendapatkan informasi terkait hal yang telah di teliti.Bagi Instansi meningkatkan derajat kesehatan mahasiswa khusunya di universitas-universitas di Kalimantan Selatan dengan peningkatan program penyuluhan dan sosialisasi berupa pemberian informasi serta edukasi tentang Kawasan Tanpa Rokok di ruang lingkup pendidikan.

\section{UCAPAN TERIMA KASIH}

Ucapan terima kasih disampaikan kepada Kemenristik Dikti yang telah mendanai penelitian ini, yang kedua seluruh Universitas Swasta yang ada di Banjarmasin, yang ketiga kepada teman-teman Tim Peneliti yang telah membuat penelitian ini.

Indonesia; 2013. [Online] [Akses 8 April 2014] available on www.depkes.go.id/downloads/riskesdas 2013/Hasil\%20Riskesdas\%202013.pdf

4. Notoatmodjo, S. Metodelogi Penelitian Kesehatan. Jakarta: Rineka Cipta; 2010.

5. Notoatmodjo, S. Promosi Kesehatan dan Ilmu Perilaku. Jakarta : Rineka Cipta; 2007.

6. Azwar, S. Sikap Manusia Teori dan Pengukurannya. Yogyakarta: Pustaka Pelajar; 2003.

7. Shaluhiyah, Z.,Karyono.,\& Noor, F. Faktor-Faktor Yang Berpengaruh Terhadap Praktik Merokok Pada 
Remaja Sekolah Menengah Pertama DiKabupaten Kudus Tahun 2005. Jurnal Promosi Kesehatan Indonesia; $2006: 1$ (1)

8. Azwar, S. Sikap Manusia Teori dan Pengukurannya, adisi 2, Yogyakarta : Pustaka Pelajar; . 2007.

9. Salman Alfarisy. Efektifitas pedidikan kesehatan terhadap peningkatan kesehatan terhadap peningkatan pengetahuan remaja tentang dampak merokok. Skripsi; 2014.

10. Pramodya, RD. Pengaruh Penyuluhan Mengenai Imunisasi Terhadap Pengetahuan Dan Sikap Ibu Di Desa Sukarapih Kec. Sukasari. Fakultas Kedokteran Universitas Padjadjaran; 2015.

11. Meliono, Irmayanti. Pengetahuan [monograph on the Internet]. Jakarta: Lembaga Penerbitan FEUI; 2007.

12. Palupi, A.I, Hubungan antara Kebiasaan Makan Pagi dengan ingkat Kesegaran jasmani pada Siswa SD Negeri di Kelurahan Trangasan Kecamatan Gatak
Kabupaten Sukoharjo; 2011. [Diakses 12 September 2018]

13. Rusmilawaty. Pengaruh Penyuluhan Metode Ceramah tentang Bahaya Rokok terhadap Perubahan Sikap Perokok Aktif. Jurnal Vokasi Kesehatan; 2015 : Volume II Nomor 2 Juli 2016, hlm. 113 - 118.

14. Azwar, S. Sikap Manusia: Teori dan Pengukurannya (ed.4). Yogyakarta: Pustaka Pelajar; 2008.

15. Nia, Nurkania. Pengaruh Penerapan Kawasan Tanpa Rokok Disekolah Terhadap Sikap dan Prilaku Berhenti Merokok Dikalangan Siswa SMA di Kota Bogor; 2007. [Online] [Diakses tanggal 10 September 2018] dari http://puspasca.ugm.ac.id/files/Ab st_(2863-H-2007).pdf.

16. Sen, B. Analysis of Influencing an Adolescents Intention to be a NonSmoker; 2005. [Online] [Diakses pada tanggal 15 September 2018] dari http://clinmed.netprints.org/cgi/con ten/full/2000050006v1. 


\section{LAMPIRAN}

Tabel 1. Distribusi Frekuensi Responden Menurut Umur

\begin{tabular}{lcc}
\hline \multicolumn{1}{c}{ Umur } & f & \% \\
\hline$<20$ tahun & 4 & 6,89 \\
20-25 tahun & 54 & 93,11 \\
Jumlah & 58 & 100 \\
\hline
\end{tabular}

Sumber: Data Primer 2018

Tabel 2. Distribusi Frekuensi Responden Menurut Umur

\begin{tabular}{ccc}
\hline Umur & f & $(\boldsymbol{\%})$ \\
\hline$<20$ tahun & 38 & 13,19 \\
$20-25$ tahun & 250 & 86,81 \\
Jumlah & 288 & 100 \\
\hline
\end{tabular}

Sumber: Data Primer 2018

Tabel 3. Distribusi Frekuensi Responden Menurut Umur

\begin{tabular}{ccc}
\hline Umur & f & $(\boldsymbol{\%})$ \\
\hline$<20$ tahun & 2 & 100 \\
$20-25$ tahun & 0 & 0 \\
Jumlah & 2 & 100
\end{tabular}

Sumber: Data Primer 2018

Tabel 4. Distribusi Frekuensi Responden Menurut Umur

\begin{tabular}{ccc}
\hline Umur & f & $(\boldsymbol{\%})$ \\
\hline$<20$ tahun & 29 & 64,44 \\
$20-25$ tahun & 16 & 35,56 \\
Jumlah & 45 & 100 \\
\hline
\end{tabular}

Sumber: Data Primer 2018

Tabel 5. Distribusi Frekuensi Responden Menurut Pengetahuan Sebelum Diberikan Edukasi KTR

\begin{tabular}{ccc}
\hline Pengetahuan & f & $(\boldsymbol{\%})$ \\
\hline Baik & 82 & 20.87 \\
Cukup & 78 & 19.85 \\
Kurang & 233 & 59.28 \\
Jumlah & 393 & 100 \\
\hline
\end{tabular}

Sumber: Data Primer 2018 
Tabel 6. Distribusi frekuensi responden berdasarkan sikap sebelum diberikan edukasi tentang KTR

\begin{tabular}{ccc}
\hline Sikap & f & (\%) \\
\hline Positif & 245 & 62.34 \\
Negatif & 148 & 37.66 \\
Jumlah & 393 & 100 \\
\hline
\end{tabular}

Sumber: Data Primer 2018

Tabel 7. Distribusi Frekuensi Responden Berdasarkan Pengetahuan Sesudah Diberikan Edukasi tentang KTR

\begin{tabular}{ccc}
\hline Pengetahuan & f & $\mathbf{( \% )}$ \\
\hline Baik & 324 & 82.44 \\
Cukup & 53 & 13.49 \\
Kurang & 16 & 4,07 \\
Jumlah & 393 & 100 \\
\hline
\end{tabular}

Sumber: Data Primer 2018

Tabel 8. Distribusi Frekuensi Responden Berdasarkan Sikap Sesudah Diberikan Eduakasi tentang KTR

\begin{tabular}{ccc}
\hline Sikap & f & $(\mathbf{\% )}$ \\
\hline Positif & 360 & 91.6 \\
Negatif & 33 & 8.397 \\
Jumlah & 393 & 393 \\
\hline
\end{tabular}

Sumber: Data Primer 2018

Tabel 9. Uji Kenormalan Pengetahuan dan Sikap

\begin{tabular}{cccccc}
\hline $\begin{array}{c}\text { Pengeta- } \\
\text { huan }\end{array}$ & $\begin{array}{c}\boldsymbol{p} \text { - } \\
\text { value }\end{array}$ & Distribusi & Sikap & $\begin{array}{c}\boldsymbol{p} \text { - } \\
\text { value }\end{array}$ & Distribusi \\
\hline Pre test & 0.000 & $\begin{array}{c}\text { Tidak } \\
\text { normal }\end{array}$ & $\begin{array}{c}\text { Pre } \\
\text { test }\end{array}$ & 0,000 & $\begin{array}{c}\text { Tidak } \\
\text { normal }\end{array}$ \\
Post test & 0,000 & $\begin{array}{c}\text { Tidak } \\
\text { normal }\end{array}$ & $\begin{array}{c}\text { Post } \\
\text { test }\end{array}$ & 0,000 & $\begin{array}{c}\text { Tidak } \\
\text { normal }\end{array}$ \\
\hline
\end{tabular}

Sumber: Data Primer 2018

Tabel 10. Perbedaan Pengetahuan Responden Sebelum dan Sesudah Diberikan Edukasi Tentang KTR Pada Remaja di Universitas-Universitas Swasta Kalimantan Selatan

\begin{tabular}{lccc}
\hline Variabel & Mean & P value & N \\
\hline Pretest & 1,80 & 0,000 & \multirow{2}{*}{393} \\
Posttest & 2,77 & & \\
\hline
\end{tabular}

Sumber: Data Primer 2018

Tabel 11. Perbedaan Pengetahuan Responden Sebelum dan Sesudah Diberikan Edukasi Tentang KTR Pada Remaja di Universitas-Universitas Swasta Kallimantan Selatan

\begin{tabular}{lccc}
\hline Variabel & Mean & P value & N \\
\hline Pretest & 1,47 & 0,000 & 74 \\
Posttest & 2,00 & &
\end{tabular}

Sumber: Data Primer 2018 